\title{
The Impact of Zakat Fund in Reducing Poverty Case of Algeria
}

\section{Dr. Bouchikhi Mohamed Rédha}

Department of Finance, Faculty of Economic Sciences, Mustapha Stambouli University, Mascara, Algeria Email: rbouchikhi2@gmail.com

\section{Dr. Ghrissi Larbi}

Department of Finance, Faculty of Economic Sciences, Mustapha Stambouli University, Mascara, Algeria Email: larbi.ghrissi@gmail.com

\section{Phd Student. Rahmani Mira Karima}

Department of Finance, Faculty of Economic Sciences, Mustapha Stambouli University, Mascara, Algeria Email:mkrahmani88@gmail.com

\section{Doi:10.5901/mjss.2016.v7n3p256}

\section{Abstract}

Zakat is one of the pillars of Islam but also one of the pillars important the fight against poverty, in this research paper we will propose an econometric model to measure the contribution and the impact of zakat fund in Algeria in the fight against poverty from 2003 to 2013 to achieve this we have used an estimation with the OLS method. Through that we have arrived at that result which demonstrates that the Algerian zakat fund helps to create new businesses, which leads the reduction of unemployment and poverty but this contribution remains small.

Keywords: Zakat, poverty, unemployment, Algerian zakat fund.

\section{Introduction}

The scourge of poverty is increased in all countries of the world; each country tries to cope by implementing strategies to fight against poverty( EFIGIP, 2011), and it cannot have a strategy to fight against poverty without observation, without indicator, or aimless. (Gadrey J, Jany-Catrice F, 2005)

Among these vision, in 2003 Algeria adopted a strategy based on Islamic fundament, the principle was to create a fund to collect zakat, and this fund is a religious and social institution working under the supervision of ministry of religious affairs.

From, the problem of our study is:

- How zakat fund can reduce poverty and what's its contribution since its establishment in Algeria?

\section{Research Hypotheses}

- Zakat fund combats against poverty by creating business and reducing unemployment.

- Zakat fund contributes to improve the level of poorest.

\section{Importance of the Study}

The importance of the study is as follows:

- Demonstrate the role of Zakat in social solidarity to face the negative phenomena deployed in Muslim societies, especially poverty and unemployment and the resulting negative effects.

- Highlighting the role of the Zakat Found And how it makes the stability of Islamic societies through the eradication of poverty and unemployment.

- Highlight the importance of having an organization that collects the distribution of Zakat. (Minvielle J, Bry ,X, 2003) 


\section{Methodology}

To answer the problem, we propose to divide this paper into three parts, the first will be devoted to the definition and causes of poverty and its measurement in economy, the second to the zakat fund, and the last part in the empirical study using the ols method for econometric measure the relationship between Zakat fund and poverty reduction .

\section{Islamic Vision of Poverty}

\subsection{Islamic Definition of Poverty}

In the publication of the United Nations in March presented the various possible forms of poverty and that includes the absence of the back and productive resources necessary to guarantee a comfortable standard of living, and among the forrms of poverty there is hunger, bad nutrition, deteriorating health status, limited education and lack other vital services Islam gave us a precise definition of poverty as follows: «Inability to achieve sufficiency», and it's admitted that the threshold of sufficiency is the limit to the obligation to zakat.

\subsubsection{The Quranic Definition}

- The poor are the persons who lack material means, possessions or income to support them. The poor (fakir) finds himself in involuntary poverty, unable to satisfy his necessary needs. He may be disabled, handicapped, or having no assets or income, landless, unskilled, old, orphan or a poor widow.

- The destitute (miskin) is in misery, dependent on others, he is unable to work or not earning enough to maintain himself and his family. As compared to the poor (fakir), he is much below the poverty level. (Korayem ,K\& Mashhour, N, 2014)

Poverty is a complex phenomenon, it's not considered an aspect of inequality economic. It is above all the articulated motion of social and economic inequalities.

\subsubsection{Several types of poverty}

- Material Poverty: In this case, poverty can be considered as the state of someone who has little financial resources and few assets.

- Social Poverty: In this case the resources and assets allow the people to have a decent living, and given that poverty is the lack of resources available, so the poor have a disadvantaged social status. (Konan B M, Tabe $B$ N, 2012) and to identify what resources are needed, we reference to the pyramid of needs of Maslow:

\section{Graphic 1. Maslow Graphic}

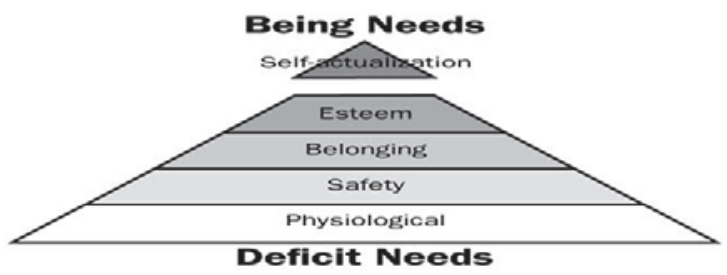

This theory was developed by psychologist Abraham Maslow in 1940, to him this pyramid allows understanding the hierarchy human needs, and with regard to the poor they don't exceed the first levels, with the few that they have they try to ensure the survival needs. (McLeod, S. A. 2014)

\subsection{Indicators of poverty}

Poverty indicators are indicators that allow us to measure the level of poverty in a country, we have chosen to present the indicators developed by UNDP "United Nations Development Program": 


\subsubsection{Human Development Index IDH:}

It is a concept appeared in 1990 under the impetus of economists Mahbub ul Haq and Amartya Sen. This index is a composite index that focuses on meeting the basic needs of individuals.

This indicator is a composite indicator, it's calculated from average of three indices: health index, affluence index and the index of education. (MIPES, 2007)

Graphic 2. IDH representation

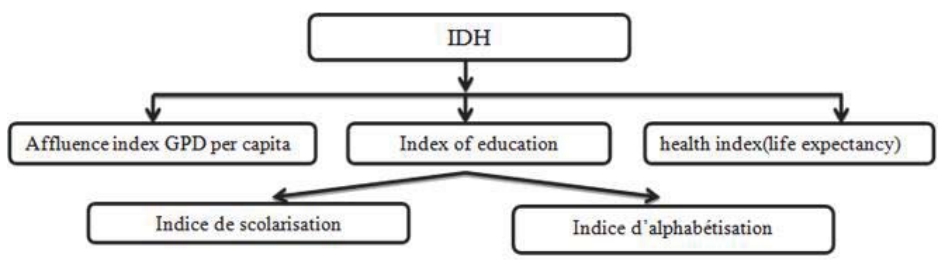

- The health index means the capacity to benefit a long and healthy life; it's measured by life expectancy at birth.

- The index of education is the ability to access to education and knowledge; it is represented by the enrollment rate and the rate of alphabetization adults.

- Wealth Index is the ability to access the necessary material resources to achieve a decent standard of living; it is calculated from GDP per capita. (http://www.marw.dz)

$\mathrm{IDH}$ is calculated by the following formula:

The health index +The index of education +Wealth Index

With, education index $=2 / 3$ (alphabetization index $)+1 / 3$ (schooling index $)$

\subsubsection{Human Poverty Index IPH}

Graphic 3. IPH representation

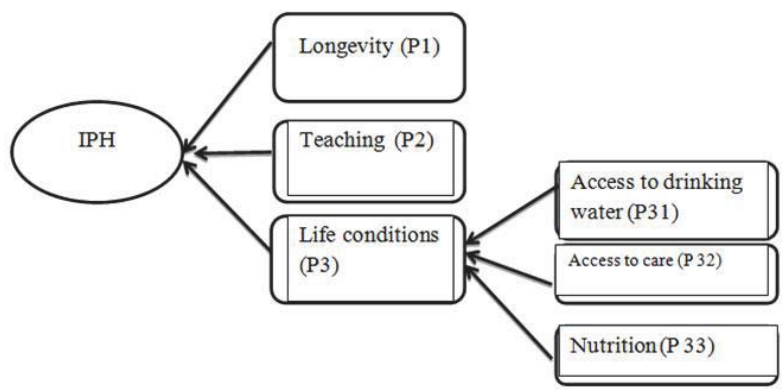

IPH is calculated by the following formula:

$\mathrm{IPH}=\left(\frac{1}{3}\left(P 1^{3}+P 2^{3}+P 3^{3}\right)\right)^{\frac{1}{3}}$, with $\mathrm{P}_{3}=\frac{P 31+P 32+P 33}{3} \quad(\mathrm{ONU}, 2010)$.

\subsection{Poverty Causes}

The main causes of poverty in Algeria are political, economic and social causes. (Gourine, $\mathrm{H}, 2014$ ) 


\subsubsection{Economic Causes}

We can Mention them on the following points lack of revenue for necessary needs such as housing , food, ... the poor need a stable work to ensure revenue, and as the country comes ensure economic growth it can reduce poverty by providing revenue, as implies it the vicious circle theory as it's illustrated in the following diagram: ,(Hadji,F, 2014).

Graphic 4. Vicious circle theory

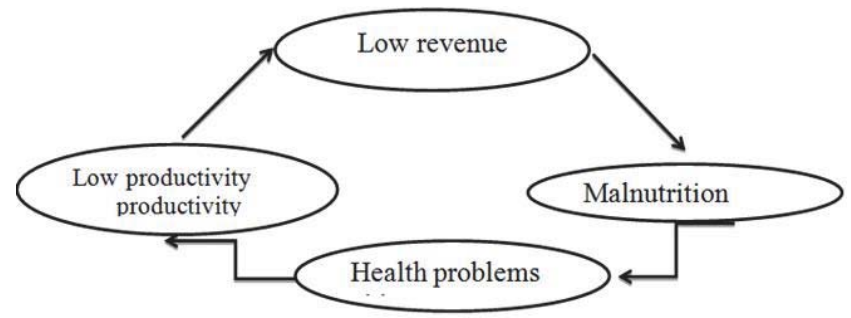

- Economic developments such as globalization, trade liberalization, privatization ... ect, don't necessarily generates economic success in some communities as they cause the deepening and widening the poverty gap.

- Unexploited of existing natural resources such as oil, agriculture and rivers leading to the fact that to consumption is higher than production.

- The lack of attention to the creation of new activities to increase the incomes and to improve the level of wealth of the nation. (Salhi,S, 2005).

\subsubsection{Political causes}

- In this dimension, we find that the geographical distribution in some countries can affect the standard of living because of the lack of resources available to individuals.

- among the social reasons, there's also the war that affect the individual's standard of living as a result of wars, and this leads to a negative impact on economic activity and on existing resources, and the embargo to countries that are at war leads to the fact that the investment stop and citizens will find that the limited local resources and so they find themselves on the threshold of absolute poverty is the inability to meet basic needs (foods and clothes).

- There's also the fact that some countries adopt the monarchy, and therefore the repartitions wealth is often in favor of the class that has the power.

\subsubsection{Social Causes}

- The inability of institutions to eradicate poverty.

- The marginalization of women in many areas, this is what affects several dimensions which leads the evolution in the poverty rate.

- The appearance of the caste system and the distinction between castes.

\section{Zakakat Fund}

As Zakat is a pillar of Islam, it's also a social and economic necessity. It achieves the physical and moral solidarity in the community to raise the question of the poor, and it constitute a mechanism for the distribution of wealth and a fair distribution of income, and is the head constitute social capital and is an economic concept.

- Algeria has established Zakat Fund, which operates under the supervision of the Ministry of Religious Affairs to reduce poverty and help to reduce the unemployment, and it works in cooperation and coordination with neighborhood committees and the Senate and religious committees (Hassas ,A , 2010). 


\subsection{Zakat Fund}

It is a religious institution under the supervision of social work and the Ministry of Religious Affairs, which guarantees him legal coverage based on the law governing the establishment of the mosque and consists of three organizational levels:

- basal Committee: its mission to identify eligible for Zakat at the level of each circle.

- Committee state: entrusted with the final study important files Zakat at the state level.

- National Committee: find the components of the Supreme Council of the Zakat Fund and the basic functions for being a regulator for everything related to Zakat Fund in Algeria.

\subsection{Zakat Fund Aims}

\subsubsection{Future Regulatory Aims of Zakat Fund (Ketouche, A , Gourine, H 2007)}

Short-Term Aims:

- Create a national card.

- implement a local information program for the management of Zakat (a gathering for distribution of Statistics).

- The Medium-Term Objectives:

- The issuance of the Fund Act of Zakat.

- Strengthen the Fund's resources to collect and distribute alms.

- Create a national electronic network of Zakat Fund.

- Permanent offices of the management of the base of Zakat Fund (in each circle).

- The adoption of electronic transfer of the right to Zakat.

- Long-term goals:

- The establishment of the National Office for Zakat.

- Electronic organization of the collection and distribution of zakat (electronic payment of Zakat, Electronic card due Zakat, ...).

- Adoption of the idea of "voluntary choice for Zakat deduction from the source".

\subsubsection{Economic and Social Aims Of The Zakat Fund: (Mesdour, $F$,2004)}

The main zakat fund objective is eradication of the scourge of unemployment and poverty that by implementing a series mechanism for creating small projects. (Mesdour, $F, 2005$ ).

The establishment of the fund Zakat Fund in cooperation with Al Baraka Bank-based Algerian meets the needs of academics, housewives and craftsmen and funding is a branch of Zakat Fund.

This through the following activities:

- Financing and support of youth employment projects.

- The financing of unemployment insurance projects.

- Micro-financing projects.

- The establishment of companies between fund investment of Zakat and Al Baraka Bank Algeria.

\subsection{Methods Of The Collect and Disbursement of Zakat Fund :(Louafi, $T$,2012)}

\subsubsection{Methods for the collect of zakat}

- The first method: the Postal order: you can get them at all post offices throughout the national territory, and put it as follows:

- Your name or sentence (Mozaqui , Mohsen ...).

- The amount paid in numbers and letters.

- The Zakat Fund Account Number of your city.

- Second method: the check: file the check to the post office by the following:

- Account number Zakat Fund of your city.

- The amount paid in numbers and letters. 
- The third method: the Zakat funds located at the level of mosques: where are placed in every mosque boxes to collect Zakat convenience of the citizens who can not be paid in the Transaction Accounts, and receives a voucher from the imam of the mosque proving that he has paid the zakat for the zakat fund.

- Fourth method: transfer of immigrants can pay their zakat by international transfer where they mention: name, national number of the Zakat Fund, the amount in words and numbers.

\subsubsection{Distribution of Zakat Money}

Zakat funds are disbursed based on the final deliberations of the Commission on the state of Zakat for the benefit of the following categories:

- First, direct subsidies to poor families: This is by priority, they give an annual amount or quarterly for the poor .

- Second, the financing of investment projects for the benefit of unemployed youth: Speak of the Zakat Fund is in Algeria raises many questions, and among the questions that present the idea of the investment from the fund Zakat, and formulas that can be based on investment, especially when it comes to rate projects that can be beneficial for the unemployed.

\subsection{Zakat Fund Evolution}

It evident that the zakat fund has evolved since its creation in 2003 in Algeria

\subsubsection{Evolution of Beneficiary Families}

Graphic 5. Evolution of beneficiary families

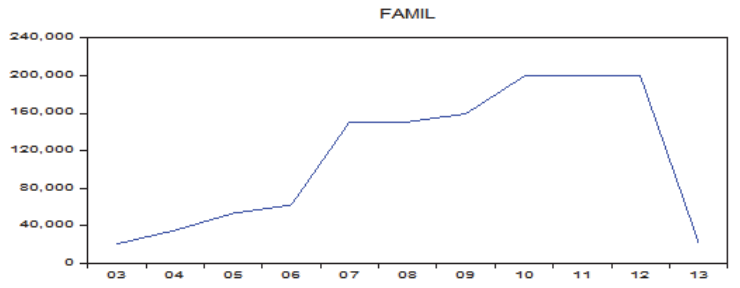

Source: Made from published data of religious affairs ministry

As we see it in the graph above the number of beneficiary families of zakat fund is evolved, and it leaves to understand that more people adopt the method of payment which must as zakat to the zakat fund, and zakat fund supports more family, and see this development we understand that the adopted strategy is on track.

\subsubsection{Evolution of Projects Financed by Zakat Fund:}

Graphic 6 . Evolution of projects financed by zakat fund

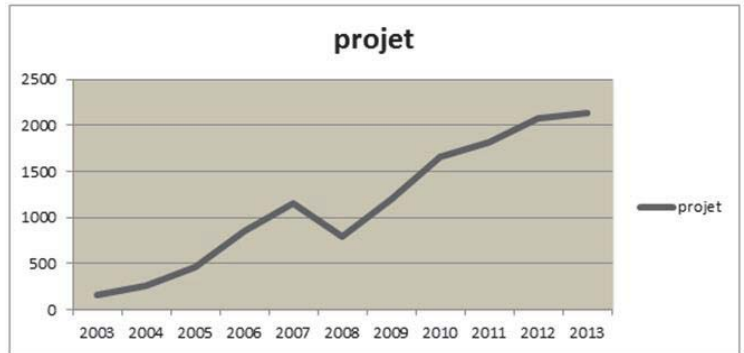

Souce: Made from published data of religious affairs ministry 
We note increase in the number projects financed by the loan-Hassan from year to year, and the objective is that these companies created after some years contribute to the financing of another company by paying their zakat to the zakat fund.

\subsubsection{Percentage share of credit}

Graphic 7. Percentage share of credit

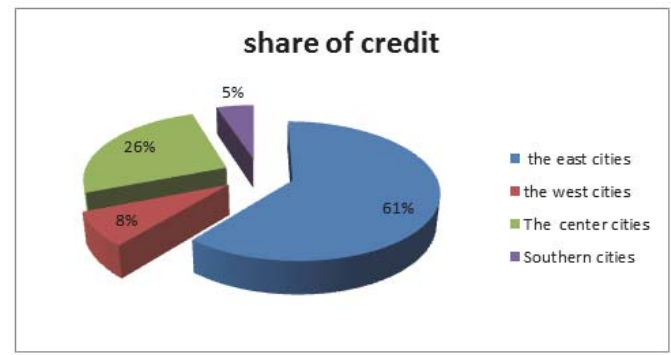

Source: Made from published brochure of zakat fund 2012

We notice that the largest share of projects funded by zakat fund is to the east and center and The decrease in west and south is due to the low rate of participation in the payment of zakat to the Fund Zakat, and it must be remedied awareness campaigns to boost public confidence and demonstrate the benefits due to pay the Zakat Zakat Fund.

- Empirical Study: Our model has been inspired by the study elaborated by H. Gebremeskel Gebremariam Tesfa G. Gebremedhin, and Randall W. Jackson, "the role of small business in economic growth and poverty . except for measuring poverty in the basic model they used public support for development, the number of companies created and the unemployment rate, for our case we keep the unemployment rate, and we exchange the two other variables with the zakat found and funded projects, The methodology involves macroeconomic analysis of the links between the increase of projects funded by zakat fund, the unemployment rate and poverty.

- Data explication: From the zakat fund there are projects funded, these projects created new jobs and, consequently its reduce unemployment rate and thus increases the HDI.

The data were collected mainly from the World Bank, data published by the ministry of religious affairs.

- Variables identification : HDI: Human Development Index is poverty indicator reflects the level of affluence of a nation they grouped some dimensions to best reflect reality.

CHOM: Unemployment rate, it is the percentage of unemployed in the labor force.

Zakat: The total amount obtained from the zakat fund.

proj: the number of project financed by zakat fund.

Stationary Test:

Table 1. Stationary test

\begin{tabular}{|c|c|c|}
\hline Variables & Level & Signification \\
\hline logidh & $1^{\text {st }}$ & 0.0004 \\
\hline logchom & $1^{\text {st }}$ & 0.01153 \\
\hline logzakat & $1^{\text {st }}$ & 0.1017 \\
\hline logproj & $1^{\text {st }}$ & 0.0015 \\
\hline
\end{tabular}

Source: Made from result of eviews

Stationary test showed that the variables are stationary at the first level with a significance level of $15 \%$

- we have introduced logarithm to make variables linear, and with using the estimate by OLS we obtained the following equation: logidh $=-0.32-0.19$ logchom +0.018 logzakat +0.01 logproj 
Economic and statistic interpretation:

- $\mathrm{R}^{2}=0.95$ and F-statistique $=0.000044$ it's less than $5 \%$, So the model is statistically robust.

- Adjusted R- squared $=0.93$, which means that $93 \%$ of variable explains $\mathrm{HDI}$ rate.

- reducing of unemployment by $1 \%$ leads to increase in the $\mathrm{HDI} 0.19$, because the integration of the unemployed in the labor force leads to an increase in GDP per capita, and therefore it has a positive effect on the $\mathrm{HDI}$ this value is statistically significant at $0.00 \%$.

- an increase in credit obtained from zakat fund $1 \%$ leads to increased in the HDI 0.018 , it's logical because these credits are intended to finance new projects and this has a positive impact on GDP per capita so it's has a positive impact on the HDI.

- when the new projects increase by $1 \%$ it leads to the increase in $\mathrm{HDI}$ of 0.12 , and as the new projects reduce unemployment and contribute to the increase of GDP per capita, therefore these new projects improve the living level and therefore the amelioration continent HDI.

- So in general we can say that the variables of the model are significant except that their contribution still weak in Algeria.

- If the number of projects financed by zakat fund projects reached 100000 , the HDI rate exceeds 10.( results obtained from an estimate from the equation model)

Durbin Watson test:

- We test the hypothesis:

$\mathrm{HO}$ : there are no positive autocorrelation residues

$\mathrm{H} 1$ : there are positive autocorrelation residues (positive error follows a positive error)

- For a number equal to 4 variables, the sample size is equal to 11 and the significance level of $5 \%$ was obtained value of DW on the table:

$\mathrm{D} 1=0.67$

$\mathrm{D} 2=1.97$

- $\quad$ The calculated $\mathrm{DW}=2.39$

The DW statistic is equal to 2.39 , the higher than 0.97 , so we accept the null $\mathrm{h}$ So all parameters are statistically significant ypothesis $\mathrm{H} 0$, there is no error autocorrelation.

Table 2. Heterostedasticity Test

\begin{tabular}{lccc} 
Heterostedasticity Test: & & \\
\hline Heterostedasticity Test: Breusch-Pagan-Godfrey & & \\
\hline \hline F-statistic & 1.637313 & Prob. F(3,7) & 0.2657 \\
Obs*R-squared & 4.535897 & Prob. Chi-Square(3) & 0.2091 \\
Scaled explained SS & 0.846316 & Prob. Chi-Square(3) & 0.8384 \\
\hline \hline
\end{tabular}

The test probability is 0.59 , it exceeds $15 \%$, which means that we accept the null hypothesis of Heteroskedasticity residual or error terms.

The specification of the error correction model is validated.

Normality test:

Now we proceed to the verification of the normality of the statistical distribution.

Table 3. Normality test
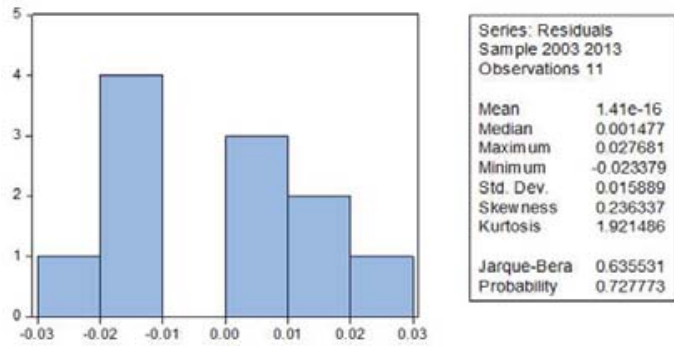

Source: Made from results of EVIEWS 
In the right table, we have the three statistics: Skewness, kurtosis and Jarque- Bera

- Jarque- Bera: The probability of the Jarque- Bera test is 0.727773 , which is above $15 \%$, which means that we accept the null hypothesis of normality of error terms or residuals.

- Skewness: The skewness is a measure of the asymmetry of the distribution of the set around its mean. For a normal distribution, the coefficient of skewness - or asymétrie- coefficient is zero and the time is of order 3. The positive skewness $(0.236337)$ means that the distribution has a tail elongated to the right.

- The kurtosis: The kurtosis measures the pointy or flat character of the distribution of the series.

Statistics kurtosis equal to 1.921486 is less than 3 , the distribution curve is flattened to normal

\section{Conclusion}

The idea of creating the Zakat Fund in Algeria for the collection and disbursement of funds in a rational way, is a unique experience where they are consistent and in accordance with the principles of Islamic law and the observance of channeling funds to especially the poor.

After making a empirical study to get an idea on the contribution of zakat fund on the level of life in Algeria we arrived to deduct this:

- The Algerian zakat fund helps to create new businesses, which leads to reduction unemployment and poverty except this contribution remains small.

- The creation of new enterprises through zakat fund helps reduce unemployment.

\section{Recommendation}

- Carry out awareness campaigns to urge people to pay their Zakat payments to the Zakat Fund.

- Adoption of the publication of Zakat Fund bulletin.

- Follow the companies created from the bottom zakat until they can contribute also in zakat fund.

\section{References}

EFIGIP,(2011), job training insertion in Franche-Comté, poverty, a matter of definition and measurement, February

Gadrey J, Jany-Catrice F,(2005), The new wealth indicators, the discovery Editions, Compass Collection, pp 128 .

Gourine, $H$,(2014), The phenomenon of poverty in Algeria and their effects on the social fabric in the shadow of the financial boom , unemployment and inflation, academic, social and humanitarian A. Studies / Department of Economic Sciences, issue 12, June .

Hadji, $\mathrm{F}$ (2014), The problem of poverty in Algeria under the development programs of Algeria in the period 2005- 2015, PhD thesis in Economic, University of Mohamed Khider , Biskra .

Hassas A, (2010), Poverty definition and measurement attempts, economic research and administrative, Issue VII, June.

Ketouche, A, Gourine H, (2007), Indicators of poverty in Algeria between official pronouncements and reports of digital compared to study the experience of Malaysia in the fight against poverty. Paper presented at the International Symposium on: the experiences of the fight against poverty in the Arab and Islamic worlds, University of Blida, 1-3 July .

Konan B M, Tabe B N, (2012), Ethics and poverty, Memory Master Economic Analysis and International Development, University of Auvergne

Korayem K \& Mashhour N, (2014), Poverty in Secular and Islamic Economics; Conceptualization and Poverty Alleviation Policy, with Reference to Egypt, Topics in Middle Eastern and African Economies, Vol. 16, No. 1, May.

Louafi T (2012), Zakat role in tackling the problems of unemployment and poverty : the experience of the Zakat Fund Algerian, Center for Environmental Studies and Sustainable Development,University of Tebessa ,Algeria

McLeod,S.A.(2014). Maslow's Hierarchy of Needs. Retrieved from www.simplypsychology.org/maslow.html

Mesdour F, (2004), Zakat Fund Algerian experience, the training course for administrative, financial and marketing aspects of the institutions of Zakat, Beirut, 6-10 December .

Mesdour F, (2005), Endowment and Zakat and their role in supporting investment and combat unemployment, a national forum on investment and operating in Algeria, University of Sidi Bel Abbes, 10-11 May.

Minvielle J, Bry X, (2003), Criticism of the Human Poverty Index (UNDP) and proposal of a Synthetic Human Poverty Index (PHAI), Workbook CED, issue. 03-02.

MIPES,(2007), Mission for information on poverty and social exclusion in France island, UNDP synthetic index: HDI, HPI, FPI, Mars

Official website of ministry of religious affairs, http://www.marw.dz

ONU (2010), The United Nations Organization for Human Rights, Office of the United Nations High Commissioner for Human Rights, a series of health publications and human rights, issue 5 September.

Salhi,S (2005), The magazine of the mosque , Zakat Fund special issue,the Ministry of Religious Affairs and Awqaf, Algeria. 